\title{
PENGARUH JENIS BAHAN PENGEMAS TERHADAP DAYA TAHAN CABAI MERAH (Capsicum annum L.) SELAMA PENYIMPANAN DINGIN
}

\author{
Fenny Agustina $^{1 *}$ Agam Akhmad Syaukani $^{2}$ dan Fatimah Sahara ${ }^{3}$ \\ ${ }^{123}$ Program Studi Pendidikan Biologi, FKIP, Universitas Riau Kepulauan, Batam \\ Koresponden: fennyagustina@gmail.com
}

\begin{abstract}
The study was conducted over two months, from March to April 2012. This study aims to analyze the influence of type of packaging materials for durability of chilli (Capsicum annum L.) during cold storage. The method used in this study is an experimental method using a completely randomized design (CRD), which consists of four types of packaging materials, namely of chilli are packed in plastic PE, PP, PS, PS + control film with a red pepper that is stored without packaging. The parameters analyzed are severe shrinkage and the organoleptic (texture, color, aroma and overall). From the test results obtained ANAVA $F_{\text {hitung }}$ value of 203,869 is greater than the value Ftabel, both at the level of 5\% for 3,480 and 5,990 at $1 \%$ level. For the organoleptic value of PS + plastic film gives the highest yield in each test the texture attributes of 6,678. 6,500 color, aroma and overall 6,122 and 6,722. PP plastic gives the lowest result in each test the texture attributes of 3,156, 3,556 color, aroma and overall 3,333 and 3,300, this indicates that there is a very significant effect between the type of packaging materials for durability chili during cold storage.
\end{abstract}

Keyword: Type of packaging materials, Cold storage.

\section{PENDAHULUAN}

Tanaman Cabai merah (Capsicum annum L.) termasuk kelompok sayuran buah yang merupakan jenis tanaman perdu dari famili terong-terongan (Solanaceae). Tanaman Cabai merah (Capsicum annum L.) dipercaya berasal dari daerah tropika sampai subtropika di kawasan benua Amerika. Tanaman cabai merah sudah tidak asing lagi dalam kehidupan masyarakat di benua Asia, termasuk di Indonesia. Indonesia yang memiliki iklim tropis dengan intensitas curah hujan terjadi sepanjang tahun memiliki potensi yang besar dan sumber daya alam yang melimpah untuk pengembangan produk-produk pertanian, termasuk Cabai merah (Capsicum annum L.).

Salah satu alasan dipilihnya Cabai merah (Capsicum annum L.) sebagai komoditas sayuran dalam penelitian ini karena cabai merah merupakan komoditas sayuran buah yang mudah sekali rusak dibandingkan dengan komoditas sayuran lainnya, seperti sayuran jenis batang, biji dan umbi. Dalam penelitian ini, cabai merah diberikan perlakuan pengemasan menggunakan berbagai jenis kemasan plastik dan disimpan dalam lemari pendingin (refriregator). Sampai sekarang pendinginan merupakan satu-satunya cara ekonomis untuk penyimpanan jangka panjang. 
Bilamana dipilih metode penyimpanan dingin, maka salah satu teknik penyimpanan dingin untuk cabai merah dapat menggunakan teknik pendinginan ruang (cooling room) atau refriregator. Banyak bahan pengemas yang dapat digunakan untuk berbagai bahan pangan termasuk komoditas sayuran, mulai dari kemasan kertas dan karton, kemasan kayu, kemasan plastik dan masih banyak lagi jenis bahan pengemas lainnya. Adapun pengemasan disebut juga sebagai pembungkusan atau pewadahan. Pengertian dari kemasan itu sendiri adalah suatu wadah atau tempat yang dikemas dan dapat memberikan perlindungan sesuai dengan tujuannya. Dalam proses pengemasan tentu saja diperlukan pemilihan teknik pengemasan yang tepat, sehingga masa simpan bahan pangan ataupun komoditas sayuran dapat ditingkatkan. Berdasarkan latar belakang, rumusan masalah dan batasan masalah di atas maka tujuan dari penelitian ini adalah untuk membuktikan adanya pengaruh jenis bahan pengemas terhadap daya tahan Cabai merah (Capsicum annum L.) selama penyimpanan dingin.

Hipotesis atau dugaan sementara dalam penelitian ini adalah terdapat pengaruh yang nyata dalam penggunaan jenis bahan pengemas terhadap daya tahan Cabai merah (Capsicum annum L.) selama penyimpanan dingin.

\section{METODE PENELITIAN}

Metode penelitian merupakan syarat dalam suatu penelitian. Penelitian itu sendiri merupakan proses ilmiah yang mencakup sifat formal dan intensif. Karakter formal dan intensif karena terkaitnya dengan aturan, urutan, maupun cara penyajiannya agar memperoleh hasil yang diakui dan bermanfaat bagi kehidupan manusia. Intensif dengan menerapkan ketelitian dan ketepatan dalam melakukan proses penelitian agar menjadi hasil yang dapat dipertanggung jawabkan.

\section{Desain Penelitian}

Metode yang digunakan dalam penelitian ini adalah metode eksperimen yang dilakukan untuk menguji pengaruh variabel bebas terhadap variabel terikat. Variabel merupakan segala sesuatu yang akan menjadi objek pengamatan penelitian atau yang dinyatakan sebagai variabel penelitian. Adapun variabel terikat yang menjadi pengujian dalam penelitian ini adalah daya tahan Cabai merah (Capsicum annum L.), sedangkan variabel bebas sebagai perlakuan dalam penelitian ini adalah jenis bahan pengemas. Desain 
percobaan yang dipakai dalam penelitian ini adalah rancangan acak lengkap (RAL), yang terdiri dari :

1. kontrol ( Cabai merah yang disimpan tanpa pengemasan ).

2. Cabai merah yang dikemas dengan plastik PP

3. Cabai merah yang dikemas dengan plastik PE

4. Cabai merah yang dikemas dengan plastik PS

5. Cabai merah yang dikemas dengan plastik PS+Film

Pada masing-masing perlakuan dilakukan tiga kali pengulangan

\section{Tahap Penelitian}

Penelitian ini terdiri dari empat tahapan, dimana tahap pertama merupakan tahapan persiapan alat dan objek yang akan digunakan. Dalam tahapan ini dilakukan pemilihan jenis bahan pengemas (PE, PP, PS, PS+LMF) dan pemilihan komoditas sayuran (cabai merah). Selanjutnya bahan pengemas (PE, PP, PS, PS+LMF) dilubangi terlebih dahulu dan untuk komoditas sayuran (cabai merah) dilakukan proses sortasi dan trimming. Pada tahap kedua dilakukan tahap perlakuan, dalam tahap perlakuan ini cabai merah sebanyak 150 gram dimasukan ke dalam masing-masing bahan pengemas (PE, PP, PS, PS+LMF). Setelah diberikan perlakuan pada masing-masing cabai merah, selanjutnya dilakukan tahap pengamatan, yaitu mengamati perubahan susut berat pada cabai.

Pada tahap keempat dilakukan proses pengumpulan data, proses pengumpulan data dimulai dengan melihat perubahan-perubahan yang terjadi pada cabai merah untuk masingmasing jenis kemasan (PE, PP, PS, PS+LMF) selama disimpan dalam pendingin (refriregator) (5-7\%). Tahap akhir merupakan tahap pengolahan data yang diperoleh dengan rancangan acak lengkap (RAL). Dan dilanjutkan dengan teknik analisa data menggunakan analisis variansi (ANAVA).

\section{Parameter Penelitian}

Pengukuran susut berat dilakukan dengan cara menimbang Cabai merah (Capsicum annum L.) sebelum penyimpanan dan sesudah penyimpanan. Menurut Sudarso (2000) dalam Rachmawati (2007) persentase susut berat dapat dihitung dengan rumus :

$$
\% \text { Susut Berat }=\frac{X-Y}{X} \times 100 \%
$$




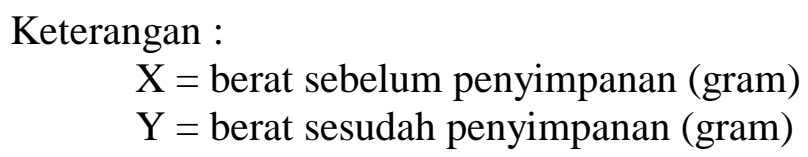

\section{HASIL DAN PEMBAHASAN}

Dalam penelitian ini parameter yang diamati adalah susut berat dan nilai organoleptik (tekstur, warna, aroma dan overall). Pada penelitian ini untuk skala uji organoleptik digunakan uji hedonik. Menurut Pudji (2001) uji hedonik adalah uji kesukaan yang merupakan jenis uji penerimaan. Skala hedonik dapat direntangkan menurut skala yang dikehendaki. Dalam analisisnya skala hedonik ditransformasikan menjadi skala numerik dengan angka menaik menurut tingkat kesukaan. Dengan adanya skala hedonik ini secara tidak langsung uji dapat digunakan untuk mengetahui adanya perbedaan. Berikut adalah hasil dan pembahasan yang diperoleh selama penelitian.

\section{Parameter Susut Berat}

Susut diartikan sebagai bagian berat (bobot) yang hilang karena adanya suatu proses. Susut pascapanen dapat dibedakan menjadi tiga macam kategori yang masingmasing mempunyai implikasi ekonomis, antara lain susut fisik yang dapat diukur dengan berat (gram), susut kualitas yaitu, karena adanya perubaha wujud, cita rasa, warna atau tekstur yang menyebabkan bahan menjadi kurang disukai oleh konsumen dan yang terakhir adalah susut nilai gizi. Pada susut berat ada dua hasil yang diperoleh dalam penelitian ini yaitu hasil pertama yaitu perhitungan dengan cara berat cabai merah sebelum penyimpanan dikurang dengan berat cabai merah setelah penyimpanan dan hasil kedua yaitu persentase susut berat. Berikut akan disajikan tebel deskripsi susut berat.

Tabel 1. menunjukkan susut berat terendah pada ketiga ulangan diperoleh pada perlakuan PS+Film yaitu 12,333 gram atau 7\% untuk ulangan pertama, 9,667 gram atau $6 \%$ untuk ulangan kedua dan 6,000 gram atau 4\% untuk ulangan ketiga. Sedangkan susut berat tertinggi untuk tiap-tiap ulangan diperoleh oleh perlakuan PP yaitu 36,667 gram atau $21 \%$ untuk ulangan pertama, 38,667 gram atau 23\% untuk ulangan kedua dan 38,333 gram atau 25\% untuk ulangan ketiga. Pengaruh jenis bahan pengemas terhadap pengukuran susut berat dapat dilihat pada Gambar 1. 
Tabel 1.Deskriptif Susut Berat (gram) Untuk Tiap-tiap Ulangan

\begin{tabular}{|c|c|c|c|c|c|}
\hline PERLAKUAN & \multicolumn{3}{|c|}{ ULANGAN I } & Rata-rata & $\%$ \\
\hline PP & 35 & 38 & 37 & 36,667 & $21 \%$ \\
\hline PE & 28 & 32 & 35 & 31,667 & $18 \%$ \\
\hline PS & 20 & 19 & 19 & 19,333 & $11 \%$ \\
\hline PS+Film & 17 & 11 & 9 & 12,333 & $7 \%$ \\
\hline Kontrol & 76 & 76 & 76 & 76,000 & $43 \%$ \\
\hline PERLAKUAN & \multicolumn{3}{|c|}{ ULANGAN II } & Rata-rata & $\%$ \\
\hline $\mathrm{PP}$ & 37 & 39 & 40 & 38,667 & $23 \%$ \\
\hline PE & 24 & 28 & 25 & 25,667 & $15 \%$ \\
\hline PS & 13 & 15 & 13 & 13,667 & $8 \%$ \\
\hline PS+Film & 10 & 12 & 7 & 9,667 & $6 \%$ \\
\hline Kontrol & 80 & 80 & 80 & 80,000 & $48 \%$ \\
\hline PERLAKUAN & \multicolumn{3}{|c|}{ ULANGAN III } & Rata-rata & $\%$ \\
\hline PP & 37 & 35 & 43 & 38,333 & $25 \%$ \\
\hline PE & 25 & 27 & 26 & 26,000 & $17 \%$ \\
\hline PS & 16 & 12 & 6 & 11,333 & $7 \%$ \\
\hline PS+Film & 5 & 8 & 5 & 6,000 & $4 \%$ \\
\hline Kontrol & 73 & 73 & 73 & 73,000 & $47 \%$ \\
\hline
\end{tabular}

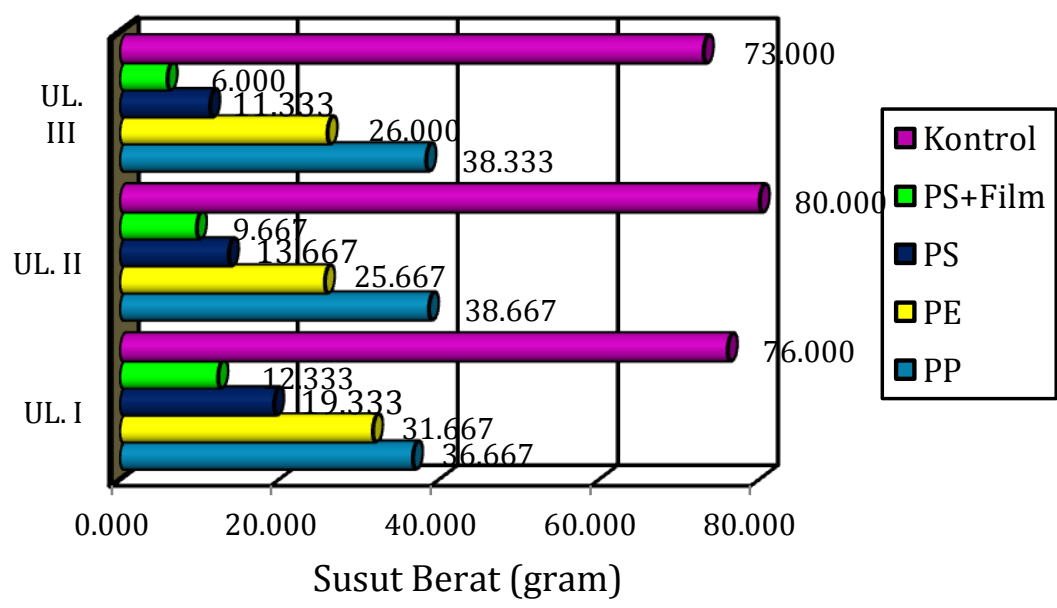

Gambar 1. Histogram Pengukuran Susut Berat Untuk Tiap-tiap Ulangan

Dari Gambar 1. di atas dapat dilihat bahwa susut berat terendah pada ketiga ulangan diperoleh pada perlakuan PS+Film yaitu 12,333 gram untuk ulangan pertama, 9,667 gram untuk ulangan kedua dan 6,000 gram untuk ulangan ketiga. Sedangkan susut berat tertinggi untuk tiap-tiap ulangan diperoleh oleh kontrol (tanpa pengemasan) yaitu 76,000 gram untuk ulangan pertama, 80,000 gram untuk ulangan kedua dan 73,000 untuk ulangan ketiga. Dan untuk mengetahui lebih lanjut lagi maka dilakukan perhitungan susut berat sebagai berikut. 


\section{Perhitungan Nilai Susut Berat}

Untuk mengetahui nilai susut berat dari ketiga ulangan maka dilakukan perhitungan seperti pada Tabel 2. di bawah ini.

Tabel 2. Perhitungan Susut Berat (gram)

\begin{tabular}{cccccc}
\hline \multirow{2}{*}{ Perlakuan } & \multicolumn{3}{c}{ Ulangan } & \multirow{2}{*}{ Total } & \multirow{2}{*}{ Rata-Rata } \\
\cline { 2 - 4 } & I & II & III & & \\
\hline Kontrol & 76,000 & 80,000 & 73,000 & 229,000 & 76,333 \\
PP & 36,667 & 38,667 & 38,333 & 113,667 & 37,889 \\
PE & 31,667 & 25,667 & 26,000 & 83,334 & 27,778 \\
PS & 19,333 & 13,667 & 11,333 & 44,333 & 14,778 \\
PS+Film & 12,333 & 9,667 & 6,000 & 28,000 & 9,333 \\
\hline & & & & 498,334 & \\
\end{tabular}

Dari nilai rata-rata yang diperoleh pada Tabel 2. di atas terlihat bahwa susut berat yang terendah diperoleh pada perlakuan PS+Film yaitu hanya 9,333 gram selama penyimpanan empat minggu dan susut berat yang tertinggi yaitu pada perlakuan PP yaitu 37,889 gram. Hal ini menunjukkan bahwa PS+Film (Polistiren dikombinasikan dengan Film) lebih efektif dibandingkan ketiga perlakuan (PP, PE, PS) dan kontrol, jika digunakan sebagai pengemas Cabai merah (Capsicum annum L.) selama penyimpanan dingin karena ketiga perlakuan (PP, PE, PS) kurang mampu menghambat terjadinya kenaikan susut berat yang sangat besar pada Cabai merah (Capsicum annum L.). Dengan dikombinasikannya PS dengan Film maka kondisi atmosfir dalam ruang kemasan memiliki kestabilan udara yang cukup terkendali yang dapat menghambat kenaikan susut berat. Hasil perhitungan susut berat dapat dilihat dari Gambar 2. di bawah ini.

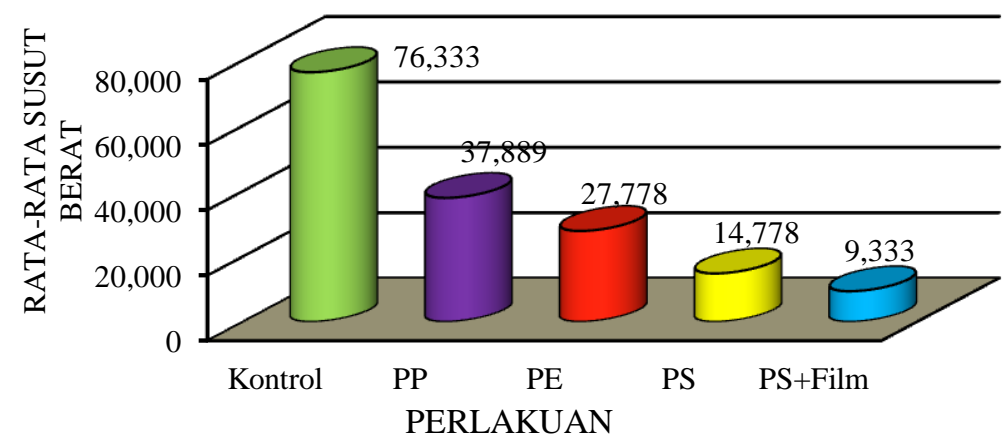

Gambar 2. Susut Berat 
Kehilangan susut berat pada Cabai merah (Capsicum annum L.) selama disimpan terutama disebabkan oleh kehilangan air yang dapat menimbulkan kerusakan. Nilai susut berat seperti pada Gambar 2. dapat di transformasikan ke dalam persentase seperti Gambar 3. berikut.

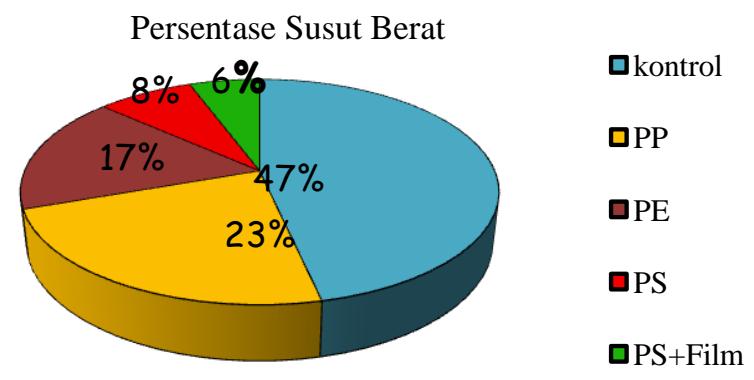

Gambar 3. Histogram Persentase Susut Berat

Dari Gambar 3. Nilai susut berat dapat dilihat bahwa susut berat terendah diperoleh pada perlakuan PS+Film yaitu 9,333 gram atau 6\%. Sedangkan susut berat tertinggi diperoleh perlakuan PP yaitu 37,889 gram atau 23\%. Hal ini menunjukkan bahwa cabai merah yang disimpan dengan perlakuan PS+Film dapat menghambat laju kenaikan susut berat selama penyimpanan dingin dan merupakan jenis bahan pengemas yang paling efektif jika dibandingkan dengan perlakuan PP, PE, PS yang tidak mampu menekan laju kenaikan susut berat pada cabai merah selama penyimpanan dingin. Semakin tinggi laju kenaikan susut berat maka semakin banyak kehilangan air yang akan menyebabkan terjadinya pelayuan dan pengkeriputan (Muchtadi $d k k$. 2011). Untuk perhitungan Anava disajikan dalam Tabel 3. berikut.

Tabel 3. Perhitungan Anava Susut Berat

\begin{tabular}{ccccccc}
\hline Sumber & Derajat Bebas & Jumlah & Kuadrat Total & \multirow{2}{*}{$\mathrm{F}_{\text {hitung }}$} & \multicolumn{2}{c}{$\mathrm{F}_{\text {tabel }}$} \\
\cline { 6 - 8 } Keragaman & $(\mathrm{db})$ & kuadrat $(\mathrm{JK})$ & $(\mathrm{KT})$ & & 0,05 & 0,01 \\
\hline Perlakuan & 4 & 8462,601 & 2115,650 & 203,869 & 3,480 & 5,990 \\
Galat & 10 & 103,775 & 10,378 & - & - & - \\
\hline Total & 14 & 8566,376 & - & - & - & - \\
\hline
\end{tabular}

Berdasarkan perhitungan anava pada Tabel 3. di atas dapat dilihat bahwa hasil $\mathrm{F}_{\text {hitung }}$ lebih besar jika dibandingkan dengan $\mathrm{F}_{\text {tabel }}$. Maka dilanjutkan dengan uji signifikasi yaitu dengan uji BNT (Beda Nyata terkecil) taraf 5\%. Uji BNT (Beda Nyata Terkecil) disajikan pada Tabel 4. di bawah ini. 
Tabel 4. Notasi Uji BNT (Beda Nyata Terkecil) Susut Berat

\begin{tabular}{cccc}
\hline \multirow{2}{*}{ Perlakuan } & Rata-rata & 0,05 & 0,01 \\
\cline { 3 - 4 } & & $\mathrm{a}$ & $\mathrm{a}$ \\
PS+Film & 9,333 & $\mathrm{~b}$ & $\mathrm{~b}$ \\
PS & 14,778 & $\mathrm{c}$ & $\mathrm{c}$ \\
PE & 27,778 & $\mathrm{~d}$ & $\mathrm{~d}$ \\
PP & 37,889 & $\mathrm{e}$ & $\mathrm{e}$ \\
Kontrol & 76,333 & . Notasi) \\
\hline
\end{tabular}

Dari Tabel 4. di atas dapat dilihat bahwa jenis bahan pengemas memberikan pengaruh yang sangat berbeda nyata terhadap susut berat cabai merah selama penyimpanan dingin selama empat minggu. Nilai susut berat terendah diperoleh pada bahan pengemas PS+Film yaitu 9,333, sedangkan nilai susut berat tertinggi diperoleh pada perlakuan PP yaitu sebesar 37,889. Hal ini dikarenakan jenis bahan pengemas PS+Film memiliki permeabilitas uap air dan gas yang tinggi terhadap keluar masuknya oksigen dan karbondioksida jika dibandingkan dengan perlakuan PP yang permeabilitas uap air dan gasnya rendah terhadap keluar masuknya oksigen dan karbondioksida. Selain itu jenis bahan pengemas PS+Film memiliki titik lebur yang rendah jika dibandingkan dengan perlakuan PP dan PE. Kehilangan air dalam jumlah yang banyak selama penyimpanan tidak hanya menurunkan berat, tetapi juga dapat menurunkan tingkat kerusakan seperti pelayuan dan pengkeriputan.

\section{KESIMPULAN}

Berdasarkan hasil pengujian hipotesis dan penelitian pengaruh jenis bahan pengemas terhadap daya tahan Cabai merah (Capsicum annum L.) selama penyimpanan dingin terhadap parameter susut berat yang diamati selama penelitian, maka dapat ditarik kesimpulan sebagai berikut :

1. Dari hasil yang diperoleh, bahan pengemas PS+Film memberikan nilai uji yang terbaik untuk kedua parameter yaitu susut berat dan organoleptik. Bahan pengemas PS yang dikombinasikan dengan Film paling efektif menghambat laju kenaikan susut berat dan mempertahankan daya tahan cabai merah selama penyimpanan dingin hingga waktu 4 minggu jika dibandingkan dengan bahan pengemas PP, PE dan PS.

2. Bahan pengemas PS yang dikombinasikan dengan Film paling efektif menghambat laju kenaikan susut berat dan mempertahankan daya tahan cabai merah selama penyimpanan dingin karena bahan pengemas PS+Film memiliki permeabilitas uap air 
dan gas yang tinggi terhadap keluar masuknya Oksigen dan Karbondioksida, sehingga kondisi atmosfir dalam ruang kemasan memiliki kestabilan udara yang cukup terkendali. Selain itu bahan pengemas PS+Film juga memiliki titik lebur yang rendah.

\section{REFERENSI}

Arpah. 2001. Buku \& Monograf Penentuan Kadaluawarsa Produk Pangan, Program Studi Ilmu Pangan, Program Pasca Sarjana, Institut Pertanian Bogor. Bogor.

Irsal, L., Subagyono K, dan A.P. Setiyanto. 2006. Isu dan Pengelolaan Lingkungan Dalam Revitalisasi Pertanian. J Litbang Pertanian : Vol. 25, No. 3, Hal 106-114.

Kartasapoetra, A. G. 1994. Teknologi Penanganan Pascapanen. Bina Aksara. Jakarta.

Muchtadi, T. R, Sugiyono, Fitriyono, A. 2011. Ilmu Pengetahuan Bahan Pangan, Penerbit Alfabeta.

Muwarni, R. 2006. Tren Kemasan Praktis \& Inovatif. Bul Foodreview Referensi Industri \& Teknologi Pangan Indonesia : Vol. I, Ed 1 : 38.

Novita, N. 2009. Pengaruh Jenis Bahan Pengemas Terhadap Kualitas Cabai Merah (Capsicum annum L.) Segar Kemasan Selama Penyimpanan Dingin. http://repository.usu.ac.id/bitstream/123456789/4680/1/09E00284.pdf. Diunduh [Tanggal 11 Februari. Jam 14:32].

Prajnanta, F. 2004. Kiat Sukses Bertanam Cabai, Penebar Swadaya. Jakarta

Pudji, W. R. 2001. Penuntun Pratikum Penilaian Organoleptik, Jurusan Teknologi Pangan Dan Gizi, Fakultas Teknologi Pertanian, Institut Pertanian Bogor, Bogor.

Rachmawati, R. 2009. Pengaruh Suhu dan Lama Penyimpanan Terhadap Kandungan Vitamin C Pada Cabai Rawit Putih (Capsicum frustencens). J. Biologi XIII (2) : (36-40).

Rukmana, R. dan Y. Yuaniarsih. 2005. Penanganan Pascapanen Cabai Merah. Yogyakarta : Kanisius.

Safaryani, N. 2007. Pengaruh Suhu dan Lama Penyimpanan Terhadap Kadar Vitamin C Brokoli (Brassica olearacaea L.). Bul Foodreview Referensi Industri \& Teknologi Pangan Indonesia : Vol. XV, Ed 2 : Hal 40.

Santika, A. 2007. Agribisnis Cabai. Jakarta : Penebar Swadaya.

Sitinjak, K., T. Karo-Karo, S. Siahaan, dan A. Purba. 1993. Teknologi Pascapanen BuahBuahan dan Sayur-Sayuran. KP-USU, Medan.

Sastrosupadi, A. 2000. Rancangan Percobaan Praktis Dalam Bidang Pertanian, Kanisius,Yogyakarta. 
Sugiyono. 2011. Statistika Untuk Penelitian. Alfabeta, Bandung.

Soekarto, S. T., Musa, H. Metode Penelitian Organoleptik, Pusat Antar Universitas Pangan Dan Gizi (PAU), Institut Pertanian Bogor, Bogor.

Syarief, R dan H. Halid. 1993. Teknologi Penyimpanan Pangan, Arcan, Jakarta.

Syarief, R dan A, Irawaty. 1998. Pengetahuan Bahan Untuk Industri Pertanian, Mediayatama Sarana Perkasa. Jakarta.

Wibawa, H. 2006. Tren Kemasan Praktis \& Inovatif. Bul Foodreview Referensi Industri \& Teknologi Pangan Indonesia : Vol. I, Ed 1 : Hal 20.

Winata, S. 2008. Beyond Beverage. Bul Foodreview Referensi Industri \& Teknologi Pangan Indonesia : Vol. III, Ed 2 : Hal 13.

Winarno, F. G. 1993. Pangan Gizi, teknologi, dan konsumen, Gramedia Pustaka Utama, Jakarta.

Yousda. A. 1993. Penelitian \& Statistika Pendidikan, Bumi Aksara. Jakarta. 